\title{
MEDIA INNOVATION IN EUROPE AND REINVENTION OF AUDIENCES: BETWEEN CITIZENS AND CONSUMERS
}

\author{
Iva Nenadić :: Alina Ostling
}

IZVORNI ZNANSTVENI RAD / DOI: 10.20901/ms.9.17.2 / PRIMLJENO: 21.05.2018.

\begin{abstract}
Technological transformation has provided conditions for people to engage in different stages of news production, as never before. With this in mind, this paper explores whether the media and journalists across Europe in their attempt to innovate the news business model reconsider their relations to users. More specifically, we question whether this innovation seeks to address users primarily as citizens or as consumers. The analysis is based on the data collected by national research teams through the project Media Pluralism Monitor 2016, implemented in EU:28, Montenegro and Turkey. The results show that the most visible attempts of innovation are crowdfunding/crowdsourcing and paywalls, which can be seen as a turn to audiences to compensate for a loss in advertising revenues. At the same time, only a few initiatives re-invent their relationship with audiences by giving them more decision-making powers (be it related to content or to their business strategy). Audiences are to a great extent still treated simply as paying consumers, and the level of participation remains limited.
\end{abstract}

\section{KEYWORDS}

MEDIA BUSINESS INNOVATION, CROWDFUNDING, PAYWALLS, PARTICIPATION, CITIZENS, CONSUMERS

Authors note

Iva Nenadić :: University of Zagreb, Faculty of Political Science, Zagreb / Centre for Media Pluralism and Media Freedom, European University Institute, Florence :: iva.nenadic@fpzg.hr Alina Ostling :: GLOBALCIT Programme, European University Institute, Florence :: alina.ostling@eui.eu 


\section{INTRODUCTION}

Technological developments, broad use of internet and in particular the rise of content sharing platforms have immensely changed the conditions in which news organizations operate. This new information environment has provided an opportunity for people to interact more with the media, journalists and news, as well as to provide and share their own content. User-generated content (UGC) is getting more prominence, and the relationship between media organizations and their audiences calls for reconsideration. The way media organizations employ the concept of 'audience' evolves in response to environmental changes (Napoli, 2011: 4). Media organizations traditionally have a dual function: public service and commercial activity. This dual function reflects also in their approach to users - either as citizens or as consumers. If the audiences are becoming more engaged actors of public information exchange, should media organizations, in their attempt to (re)position in the digital environment, treat them more as citizens rather than consumers? Our paper examines this question while trying to assess the nature of media business innovation across Europe in relation to the audience.

Technological advancements and the shift online are not only offering new opportunities to citizens but have also deranged the traditional media business model. Media organizations and journalistic endeavors are urged to look for alternative sources of financing. Media companies traditionally operate as a two-sided market, mediating between users and advertisers while using both of them as sources of revenue. For example, the traditional business model of newspapers is based on selling the content to readers and selling the access to readers to advertisers. The changing environment seems to disrupt this business model but not its logic. Online advertising is highly dominated by few technological companies, such as Facebook and Google (Bond, 2017), which leaves media companies with a small share to compete for. Therefore, to ensure sustainability, they are also attempting to increase people's willingness to pay for news online, and some major outlets have shown that this can work in practice'. The recent Digital News Report (Newman et al., 2017) showed that the tendency to pay for online news is growing in some countries. They found that the type of content that had most influence on the decision of people surveyed in 36 countries to pay, are breaking news (41\%) and reporting on recent events (38\%). This may point towards people's need to be informed, in order to be able to engage in peer-to-peer communication as well as in other actions. An exposure to informative content, as shown by Claes De Vreese and Hajo Boomgaarden (2006), has a positive effect on knowledge gains and participation, key elements of democratic citizenship.

Several authors in the areas of both innovation and media stress the importance of the changing relationship between companies and consumers or citizens (depending on the focus of the authors). According to Jay Rosen (2006), new media have unsettled the balance of power between the oligarchic media industry and the "people formerly known as the audience" and switched the focus to interactive, as opposed to one-

\footnotetext{
${ }^{1}$ See for example the case of The New York Times (https://www.nytimes.com/2018/02/08/business/new-york-timescompany-earnings.html) and The Guardian (https://www.ft.com/content/9044ff9a-358b-11e7-99bd-13beb0903fa3) (03/05/2018).
} 
way, communication. Digital transition has allowed people to become producers and participate at different levels of the global exchange of information. Henry Jenkins (2006) was one of the first to describe this as 'participatory culture', and to contrast it with 'consumer culture'. Even authors pertaining to a more business-oriented line of research, such as Mohanbir Sawhney et al. (2006), highlight the need for companies to reconsider the relations with their customers and recapture the value created in order to be able to innovate. In 2008, Lawrence Lessig predicted the emerging of a third type of economy. He confronted commercial economies that create value with money with sharing economies that focus primarily on value, and anticipated that an equally important hybrid economy, which builds upon both the sharing and commercial economies, would dominate, notably online (Lessig, 2008).

In an attempt to regulate the media market, media authorities, such as Ofcom in the United Kingdom, recognize interests of both citizens and consumers, as well as of the overlapping citizen-consumer (Livingston et al., 2007). "In the classic model [...] individuals were defined through their roles as 'consumers' rather than being seen as producers of or better yet, participants within - the surrounding culture", claim Henry Jenkins and Mark Deuze (2008: 5). They further note that "media companies can no longer be meaningfully studied in the absence of an understanding of how they relate to their consumers" (Jenkins and Deuze, 2008: 5).

To our knowledge, existing research on media business innovation does not raise the question as to whether the ongoing innovation considers people primarily as consumers or as citizens. With this paper we aim to add this perspective by offering an initial insight into the types of innovation that occur across Europe. We start from taking the note on the changing nature of audience that is now, more than ever, present in newsgathering, reporting, disseminating, and promoting the content online. We seek to explore whether the attempts of media organizations to innovate also reinvent their relationship with the audience: do they see them more as citizens or as consumers? While, on the one hand, exploring the potential of media innovations to promote inclusiveness and participation, on the other, we do not neglect a tendency of commercial practices to exploit participatory culture. As Denis McQuail (2010) argues, content decisions are market driven, which commodifies culture and relations with the audience.

\section{FROM CITIZEN TO CONSUMER AND TO CITIZEN-CONSUMER}

It is not uncommon to apply an audience perspective in studying the news media and journalism. Traditionally, the role of the media or journalism in society has been discussed in relation to whether the audience has been seen as citizens or as consumers (Lewis et al., 2005; Mellado and van Dalen, 2017). Dan Jackson (2007: 142) highlights that until the 1980s, when there was little direct competition between media outlets and consumption patterns were relatively stable, it was more common to think about the news media as 'citizen-centred', with their main role being to provide citizens with relevant and accurate information. Over the last 40 years, with a technology driven transformation of 
the media and information environment, commercialization, growing competition, and cultural changes, audiences are increasingly seen as consumers (Jackson, 2007: 143) - selfinterested, less active and more interested in entertainment than in political information (Mellado and van Dalen, 2017; Scammell 2000). However, to see users only as citizens or only as consumers would be far from the complex reality in which both roles are played by individuals, sometimes even simultaneously. Moreover, with more recent developments in technology, media and society the role of citizens and consumers has changed, resulting in new ways of expressing citizenship (Mellado and van Dalen, 2017: 216). As Janelle Ward and Claes De Vreese (2011:400) point out, citizenship is no longer exclusively about political participation but also about political consumption. This is linked with the notion that people today have more power (including political power) as consumers than as workers (Scammell, 2000). People are more aware of and knowledgeable about companies and their commercial practices, and "the act of consumption is becoming increasingly suffused with citizenship characteristics and considerations" (Scammell, 2000: 351). Scammell (2000: 354) also notes that the internet now provides unprecedented possibilities for citizen-consumers that can find and exchange information, organize, act and react, in ways different than before.

The point here is that, while citizen and/or consumer approaches can still be useful in understanding the relations between the media and the audience, these concepts should not be seen as strictly divided and mutually exclusive (Mellado and van Dalen, 2017; Scammell, 2000). Furthermore, the concept of 'citizen' should be altered to account for broader complexities of expressing civic engagement, including also through buying practices (Scammell, 2000). In this paper, we acknowledge these complexities. When assessing whether the innovation attempts of media organizations see their audiences primarily as citizens or as consumers, we do not exclude that they might see them as both. However, we are particularly interested in unveiling what general approach the media take, as we believe this can help us to get an initial notion of whether this innovation is revenue-oriented, or whether it has also to do with reinventing media-audience relations.

\section{IS IT ABOUT DEMOCRACY?}

The existing literature on media business innovation points towards a schizophrenic situation in which survival-related innovation drives journalism and the media in two opposite directions: turning to advertisers by offering them "native" content and promotion services which conflict with the traditional principle of separating news from advertisements (see Carlson, 2014; Küng, 2015; Laursen and Stone, 2016; Matteo and Zotto, 2015), and turning to audiences to preserve traditional standards and public interest journalism (see Aitamurto, 2011, 2015; Caravajal et al., 2012; Jian and Shin, 2015; Zaripova, 2017). Crowdfunding, a model of financing based on micro-payments from a large crowd of people, is an expression of the latter (Aitamurto, 2015). Most scholars that explored crowdfunding as a new funding model for journalism, framed it with the changing relationship between journalists and their audiences (Aitamurto, 2011; Caravajal et al., 2012; Zaripova, 2017). Tanja Aitamurto (2011) focused on one of the pioneering 
platforms for crowdfunding in journalism - Spot.Us ${ }^{2}$. Even though Aitamurto's study was conducted in 2009/2010 in the United States, and Spot.Us ceased to exist in the meantime, her findings are still relevant as more recent crowdfunding platforms in Europe do not operate much differently from the pioneering ones. From the interviews she conducted with Spot.Us donors and reporters, Aitamurto (2011) noticed that journalists develop a sense of responsibility and connection to their donors, while donors do not feel the same. Instead, their motivation, as emerging from Aitamurto's interviews, is to contribute to social change. In the context of her findings, Aitamurto (2011: 433-434) discusses crowdfunding as a "manifestation of participatory culture", that "extends from the production level [commenting on a story] to the filtering level of the process, as the community decides what stories will be reported". However, as she finds, donors do not engage much with the story process, sometimes do not even read the final story. For them, "the act of participating in crowdfunding seems to be more important than the actual journalistic product" (Aitamurto 2011: 441). If a motivation for donors to support journalism stems from a desire for a broader contribution to democracy, rather than to just a piece of reporting, as found by Aitamurto (2011), then perhaps, in this case, we should rather talk about citizens, than about media users.

Lian Jian and Jieun Shin (2015) further explored the motivation of people to crowdfund journalism, together with their demographics and media consumption patterns. They found that their belief in freedom of content is one of the intrinsic motivators, together with altruism and a sense of belonging to their community, which re-confirmed Aitamurto's (2011) findings. This self-reported concern for one's community, the wellbeing of others, and media freedom, may also be related to democratic citizenship. At the same time, it is important to remember that participants are very different and take different perspectives with regard to participation. Victor Costello and Barbara Moore, who studied viewers participating in an online activity involving a television series, found that there were viewers who just wanted to share their experiences with other viewers, which permitted them to gain a more informed position as a consumer of a media product. These viewers were not interested in influencing a program or the media in general. Alongside, there were viewers who aimed at more decision-making power and were keen to "inform the production process and create their own, 'improved' versions of their favourite programme" (Costello and Moore, 2007 in Aslama and Napoli, 2010: 16).

In the past, participation in decisions about content was rarely possible within traditional media structures. In a crowdfunded media environment, the interaction between journalists and their donors has become more common. As showed by Adilya Zaripova (2017), readers can take more active part in the reporting process by becoming experts or even hosts. However, Zaripova (2017:62) also notes that journalists perceive this new interaction as time-consuming and as adding psychological pressure to their daily job. All journalists interviewed in her study have reported to have experienced conflicts with readers who believe that being a donor gives them a right to control journalists. Some other authors (Aitamurto, 2011; Mitchelstein, 2011; Viscovi and Gustafsson, 2013)

\footnotetext{
${ }^{2}$ Spot.Us ceased to exist in 2015: http://mediashift.org/2015/03/why-crowdfunded-journalism-pioneer-spot-us-died/ $(05 / 05 / 2018)$.
} 
as well suggested that journalists are reluctant to interact with the audience due to an increased workload or the fear of losing control, and even due to increasing harassment of journalists, especially online (Löfgren Nilsson and Örnebring, 2016).

Another line of studies, focusing on user-generated content in the newsroom and channels of participation offered by news organizations, explored how open journalists and media organizations are to this new type of interaction, and what approach they take towards their audiences. José Alberto García-Avilés's (2012) analysis of audience participation in Spanish television channels resulted in a classification of eight visions of the public and related strategies: consumers, players, followers, commentators, citizens, collaborators, benefactors and activists. "The strategy of citizens' involvement intends to involve viewers in communicative, cultural, social and political processes which strengthen their rights as individuals", explained García-Avilés (2012: 438), noting also that the audience gave high ratings to this approach. However, as his findings imply, broadcasters still tend to orient towards the most commercial strategy of seeing viewers primarily as consumers, despite a more interactive environment.

Our paper aims to continue with this line of thought by exploring how the media and journalists across Europe attempt to innovate the news business model, and whether this innovation seeks to address users primarily as citizens or as consumers. We have adopted a broad focus on innovative initiatives, by including both legacy media and completely new endeavors. The aim is to complement the existing research that, on the one hand, shows that some people who engage in crowdfunding platforms feel excitement for taking more active part in the reporting process, and have strong incentives to act as citizens by supporting media freedom, while, on the other hand, journalists and traditional media organizations still largely hold the stance towards the audience, not making the participation really open.

We are interested in initiatives undertaken by both traditional and new media organizations, and our understanding of innovation is in line with the framework provided by Tanja Storsul and Arne H. Krumsvik (2013). They argue that media innovation needs to be understood in relation to what is changing, as well as to what extent something needs to be new to be considered an innovation. To answer the latter, they distinguish "innovation" from "invention", highlighting that: "A key to understanding innovation is that existing knowledge is implemented in new contexts and that this opens up new possibilities" (Storsul and Krumsvik, 2013: 17). With regard to the question of what is changing, Storsul and Krumsvik (2013) advise to assess media innovation at the level of products, processes, positions and paradigms, but also at the level of social implications, interactions and user behavior. In the following sections, we will attempt to carry out a preliminary analysis of some instances of media innovation in Europe and assess how these consider users: as citizens or as consumers. 


\section{DATA AND METHODOLOGY}

Two main research questions drive this study: (1) What kind of initiatives are media organizations developing in order to explore alternative sources of revenue? (2) Are these initiatives primarily oriented towards users-as-citizens, or users-as-consumers?

The analysis is largely based on the data collected through the 2016 implementation of the Media Pluralism Monitor in EU:28, Montenegro and Turkey. The Monitor is a research project designed to regularly assess the state of play of media pluralism in the $\mathrm{EU}$ and its accession countries. The project is coordinated by the Centre for Pluralism and Media Freedom $(C M P F)^{3}$ at the European University Institute, while the data are collected by national media experts ${ }^{4}$ who mainly relied on desk-based research, their expertise, and in some cases interviews with other country experts. The Monitor is composed of four areas, which represent the key parameters against which to measure risks to media pluralism in any given media landscape, namely: (1) Basic protection: including safeguards of freedom of expression, the right to information, and journalistic freedom; (2) Market plurality: focusing on media concentration, transparency of media ownership, commercial influence over editorial content, and media viability; (3) Political independence of media organizations; (4) Social inclusiveness: focusing on access to the media for different cultural and social groups, and on the level of media literacy for the population as a whole. The data used for this analysis were collected within the area of Market plurality, more specifically, within the variable of the indicator on media viability assessing whether traditional or new media organizations in the respective country develop initiatives that seek to explore alternative sources of revenue. National experts were instructed to report initiatives undertaken by both traditional and new media organizations. The data collected are by no means complete and do not contain all innovative initiatives in a specific country. It is, however, indicative, as it contains some of the most prominent examples identified by national media experts based on desk research and their sectoral expertise. To complement the Monitor data, the authors of this paper have also carried out additional desk-based research and examined academic literature, media reports and documents produced by international bodies.

\section{The innovation radar as analytical framework}

To make sense of the media innovation detected by the Monitor across 30 countries, we used the innovation radar (Sawhney et al., 2006) as a conceptual framework. The innovation radar was initially developed to consider different dimensions through which organizations, in particular large industry players, can innovate. It was further applied by Florin Vladica and Charles Davis (2009) to study small to medium-sized firms and to analyze media innovations. Sawhney et al. (2006: 76) define business innovation as the "creation of substantial new value for customers and the firm by creatively changing one or more dimensions of the business system". The innovation radar has twelve different dimensions of innovation grouped under four business anchors: presence, offerings, processes and customers (Sawhney et al., 2006: 77).

\footnotetext{
$\overline{3}$ To which the two authors are affiliated.

${ }^{4}$ In all the countries covered, except in Italy and Malta, for which the data collection was carried out by CMPF centrally.
} 
1. Presence that consists of the firm's channels of distribution, including network and the brand;

2. Offerings include the firm's products and services - platforms and solutions;

3. Processes refer to business activities that are used to conduct internal operations (organization and supply chain);

4. Customers refer to users or consumers (individuals and organizations), their needs, values and experiences.

Even though this categorization may have its limitations and in some cases innovation spills over several of these anchors, it informed initial analysis and brought our attention to the category of customers (referring also to users, to consumers and, in some cases, to citizens), which showed to be the most vivid line of innovation. Therefore, the second step of the analysis was to examine the level of participation offered by the initiatives categorized within that anchor.

\section{Levels of participation}

To understand if the public is conceived primarily as citizens or as consumers in the instances of media innovations detected by the Monitor, we examine the degree to which users are involved in production of content and even in management of media organizations. Public participation literature generally focuses on the extent of citizen involvement and empowerment through participation. At the same time, some authors stress that not only political participation but also consumption can be empowering (Scammell, 2000, Ward and De Vreese 2011). This is why we are looking at participation both from the point of view of practical involvement and control, and from the point of view of the empowerment deriving from social responsibility-driven purchasing power.

Models for assessing the extent of participation such as Sherry R. Arnstein's renowned ladder of public participation (1969: 217) stretch from non-participation such as "manipulation" of public opinion in order to gain support, to higher steps of participation such as "consultation", "partnership" and ultimately "citizen control". An evolution of Arnstein's ladder is the IAP2 spectrum, which is a simplified framework for assessing participation. The spectrum consists of four levels (IAP2, 2007):

1. "inform": is a one-way informing approach, where the organizers promise to keep people informed by providing balanced and objective information;

2. "consult": where organizers ask for public feedback on alternatives and/or decisions, listen to concerns, and provide feedback on how public input influenced the decision; 3. "involve": where organizers work directly with the public to make sure that their concerns are understood and considered;

4. "empower": where citizens have the final decision-making power and where the organizers promise to implement what people decide.

The IAP2 framework is useful for explaining the levels of engagement, i.e. to what extent and how organizations engage stakeholders. At each rung, a different promise to the community is made and each level requires a different type of interaction. Moving 
from level one to four (as per above) the spectrum indicates an increasing level of public impact, i.e. how much influence the community has on decision-making. Unlike Arnstein's ladder, the IAP2 spectrum is not meant to be a hierarchy but a continuum (Hardy, 2015). Depending on the types of issues at stake, the type of actors involved or the outcome expected, the optimal level might vary, also during the participation process itself. The organizers and stakeholders have to jointly find the appropriate level through negotiation (Hardy, 2015).

In the literature assessing participation in the field of communications, Anna Maria Jönsson and Henrik Örnebring (2011:129) discuss the concept of power over media content and examine if consumers are increasingly becoming "active consumers" and "media producers". In this paper, we also consider Jönsson and Örnebring's (2011) participation framework, which they used to analyze to what extent people are invited to participate in online newspapers and what this participation consists of. In their analysis, they distinguish between media features that require low, medium or high levels of participation and show that integration of user production in mainstream media largely results in users conceived as consumers, and that "to frame UGC as a democratic tool could be a branding strategy for creating and upholding a close relationship to the audience. Users are identified as consumers but approached as citizens" (Jönsson and Örnebring, 2011: 141). They further note that it is difficult to achieve empowerment within the traditional media logic, and that it is more likely for this shift from user-as-consumer to user-as-citizen to occur outside existing institutional and organizational media structures.

Building on both Jönsson and Örnebring's (2011) participation framework and the IAP2 spectrum (IAP2 2007), we carried out an assessment to determine if the Monitor cases of innovation involve a low, medium or high level of participation. To understand if the public is conceived primarily as citizens or as consumers in the instances of media innovations detected by the Monitor, we examine the degree to which users are involved in production of content and in management of media organizations. We assume that on the low end of the spectrum of participation - where there is only a requirement for a financial support - users are considered primarily as consumers, who (at most) have to be provided with balanced and objective information. At the medium and high ends - where organizers ask for feedback on alternatives and even delegate some of the decisionmaking power - users are increasingly seen as citizens. The overview of the participation features and the categorization resulting from our assessment is elaborated in the following chapter.

\section{KEY MEDIA INNOVATIONS DETECTED BY THE MEDIA PLURALISM MONITOR}

According to the Monitor results, the majority of the examined countries ( 28 of 30 ) have some examples of innovation and experimentation with alternative sources of funding, although the vast majority of media companies still earn money from traditional sources of revenues. Only two countries did not report any innovative initiative in the media 
market (Luxembourg and Malta). According to the data reported, it is usually smaller or economically weaker markets that see less variety of innovation, such as Croatia, Cyprus and Estonia.

The categorization under the innovation radar (Sawhney et al., 2006) suggests that most innovations are happening in relation to digital expansion, or within the anchor of 'presence'. The increasing access to and speed of the internet opens up significant opportunities for creation and distribution of media content. Digitization of content and interactive communication with audiences are changing the way media outputs are made (Vladica and Davies, 2009). A large majority of the innovations we observed - ranging from audio podcast versions of news to combined print and online subscriptions - use digital channels of distribution and exploit the increasing quest for on-demand and multiplatform consumption of digital content. Some of them, such as the social news agency Storyful in Ireland, that tracks and verifies social media content for their clients, would not even have existed before the digital age.

Many instances of innovations across Europe reflect in new 'offerings'. These are mainly focused on profitable services such as event organization, public relations and different marketing offers. For example, in Bulgaria, the dailies Standart, 24 Chasa and Bulgaria on Air TV have developed different event management initiatives that provide them with additional sponsorship and advertising revenue. In Germany, in 2014 commercial radio broadcasters gained 2.1 percent of total revenue from events (Goldmedia, 2015).

It is also worth noting that certain innovations span over more than one dimension. For example, public relations/marketing and arrangement of music or journalism festivals often involve both 'offerings' and 'presence' since they offer a new service, but they also expanded to another market. In Turkey, the independent daily Birgün has leveraged its brand into a new domain by organizing the music event Birgünlük Festival. In Slovenia, the online media Metina lista runs media communication workshops and provides campaign management services. In Romania, the news agency Mediafax offers communication, marketing and media services to companies aiming at public debates on matters in the industry.

In terms of the anchor 'processes', the foremost instances of innovation are again happening online. An increasing digitization of content and interactive communication with audiences change the way media outputs are made (Vladica and Davies, 2009). One of the most common process innovations we detected is crowdsourcing. In Latvia, as an example, the investigative journalism project $R E$ :Baltica has used crowdsourcing, e.g. to report on heating costs. Based on heating bills that people sent in, RE:Baltica created a map (www.karstierekini.lv) that generated countless stories in the Latvian press. The review of the cases shows that many crowdsourcing initiatives tend to be one-off campaigns, while many of the initially successful initiatives last for only a few years. A prominent example of media crowdsourcing (and crowdfunding) that have closed down is Contributoria.com ${ }^{5}$.

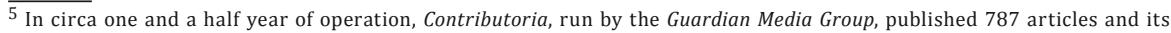
writers earned over GPB 260,000. Contributoria closed in September 2015.
} 
Insiders from the media industry emphasize that in order to sustain crowdsourcing, there is a need to invest a lot of effort into promotion, moderation of comments and dealing with challenging users, as well as ensuring that the published pieces are of high quality. ${ }^{6}$

The anchor 'customers', that relates to how media conceive their audiences, their needs, values and experiences, emerged as the most vivid line of the innovation radar within the scope of this research. The crowdfunding pointed out as the most common attempt of innovation, followed by various paywall models that aim to compensate for a loss in advertising revenues and the extinct business models. Further analysis gives a more detailed focus on paywalls and crowdfunding and the level of participation they provide, given that these are the most common innovations in the sample.

\section{Paywalls: hard and soft}

To monetize the digital content and create a viable business model, the media in Europe are also experimenting with different forms of paywall. This digital user payment scheme "acts as a barrier between an internet user and a news organization's online content" (Pickard and William, 2014: 195). Hard paywall means charging for all content on the site, while the soft paywall allows for more flexibility and free access to some content before charging (Carson, 2015; Pickard and Williams, 2014). Soft paywalls appear in various forms, such as the metered model - offering free access to a limited number of articles during the set period of time (Picard, 2014); or the premium model (also called 'freemium') - charging only for special content, like exclusive interviews, columns, deep analysis, etc. (Casero-Ripollés and Izquierdo-Castillo, 2013: 67); and micropayment - that allows readers to pay micro-amount to access individual articles within one publication or from a variety of publications, by their own choice.

The models we observed in Europe are diverse and relatively new, with many being introduced during the last two years. In the Czech Republic the business news website iHned.cz, part of the Economia publishing house, pioneered with charging for online content in 2014, allowing the free access up to 10 stories a month and some stories reported from news agencies. In 2016 they shifted from metered model to a hard paywall following disappointing results (Newman et al., 2016). Hard paywall is also used by UK's The Times and the Irish Sun. However, it seems that soft paywalls, like metered or premium (freemium) model, in general are more common than the hard walls that leave no or very little content available for free. The Irish Times operates under the metered model, as well as the Italian Corriere della Sera. In Germany Die Welt recently moved from a metered paywall to a freemium one, and the latter is also utilized by German tabloid Bild, Le Monde and Le Figaro in France, and Aftonbladet in Sweden. Instead of paying for the content of an entire media outlet, people are also offered to buy a single piece from a digital newsstand. These initiatives are noted in Slovakia, Poland and Slovenia (Piano), Germany and Netherlands (Blendle), and Poland (Webnalist). They aggregate articles from a variety of newspapers and magazines and sell them on a pay-per-article basis (micro or

\footnotetext{
${ }^{6}$ An interview with Matt McAlister, the Guardian's general manager of new digital businesses, published at: https://www. journalism.co.uk/news/contributoria-closes-but-its-team-still-sees-a-future-for-people-supported-journalism-/s2/ a566305/ (12/03/2018).
} 
nano-payments), or as a pay-per-day/month/year model. The Sweden-based magazine app for tablets and smartphones - Readly - is based on an all-you-can-read concept, that could also be described as a hardwall, allowing readers access unlimited magazines for a flat monthly fee.

Paywalls are trying to change the culture of "the free" that has consolidated on the web and makes users resistant to paying for online content (Casero-Ripollés and Izquierdo-Castillo, 2013; Goyanes, 2014). In an attempt to overcome this challenge, soft paywall models are offering their audiences personalized news and more quality content. However, it is hard to convince people to pay for online content, especially if they still have sufficient access to content for free. Also, it is hard to replicate seemingly successful models from one country to another, or even between media companies. For example, the Piano Media, which in Slovakia in 2011 introduced a paywall system for online media similar to those of the cable TV packages, and it seemed relatively promising model in its beginning ${ }^{7}$, showed much less success when expanded in Slovenia. In 2012 this digital newsstand set up a metered paywall for a group of nine Slovenian publishers, requiring readers to pay EUR 4.89 per month for access to the majority of the country's journalism. With a population of two million and due to the fact the country has its own national language, Slovenia seemed as an ideal candidate for such an approach. However, Piano did not manage to attract all relevant media companies in the country to join this unified payable system, and to put enough content behind a paywall, which resulted in a low number of subscribers and consequently a low income for the media involved.

Table 1 provides an overview of the types of paywalls identified by the Monitor, categorized by the level of participation. We categorize hard paywalls on the low end of the participation spectrum since they treat users simply as paying consumers, without granting them any decision-making power regarding content. Some would also argue that these should not even be considered as innovation. Soft paywalls that allow readers to pay micro-amounts to access individual articles are put on the medium rung of participation since they give a certain extent of power to users to decide what media content to fund. The Dutch digital newsstand startup, Blendle, which enables users to purchase individual articles is also a case in point. The initiative started in 2014 and at first it was only possible to read Dutch newspapers and one magazine, but this increased rapidly. Since 2015 German newspapers are included and Blendle aims to offer more international newspapers in the future. The uniqueness of this approach, in comparison to other paywalls observed, is that it gives people more choice in deciding what content and from which media, or from which author they want to pay for. On the one hand, this can be seen as encouraging people in making more individual choices, but the general evidence suggest that paywalls still mainly divide audiences into those who can pay for more quality journalism and those who cannot (Pickard and Williams, 2014: 7).

$\overline{{ }^{7} \text { The experiment ended in } 2016 .}$ 
Table 1. Paywall initiatives identified by the Monitor categorized by the level of participation

\begin{tabular}{lll} 
Low & Medium & High \\
$\begin{array}{l}\text { Hard paywalls charging for all } \\
\text { online content (e.g. Readly) }\end{array}$ & $\begin{array}{l}\text { Soft paywalls allowing readers to pay } \\
\text { micro-amounts to access individual } \\
\text { articles (e.g. Blendle) }\end{array}$ \\
\hline
\end{tabular}

\section{Crowdfunding and crowdsourcing}

Crowdfunding is the most common attempt of innovation. In 14 of 30 observed countries we identified the crowdfunding initiatives that are emerging and positioning themselves as an alternative not only to the traditional revenue sources for journalism, but also to the traditional model of conducting journalism. In some cases, crowdfunding even allows people to make decisions on which content should be backed. Most of the detected examples of crowdfunding, such as the French magazine Médor in Belgium, Blank Spot Project in Sweden, Direct 36 in Hungary and Pod črto in Slovenia, offer longform, analytical and/or investigative reporting.

According to the definition applied by the European Commission, crowdfunding is used for raising funds for a specific project from the public and is normally done online. The European Commission (2016: 8) distinguishes five different business models used by crowdfunding platforms: donation-based, investment-based, reward-based, lendingbased, and invoice trading crowdfunding. The most widespread business model employed by the initiatives we detected through our research is the donation-based crowdfunding. Through donation-based crowdfunding individuals donate to meet the funding aim of a project without receiving any financial or material return (European Commission, 2016: 8).

We have found instances of two forms of donation-based crowdfunding: one-time campaigns used to acquire the start-up capital, create publicity and attract bigger investors; and crowdfunding with more continuity based on the interplay between journalists and the crowd. The Monitor data shows that one-time campaigns to raise money for specific causes are run both by smaller nonprofits focusing on investigative journalism and by established publishing companies. For example, in Slovenia, the Pod črto project ('The Bottom Line'), an independent and non-profit media outlet focusing on investigative reporting, ran a campaign in 2015 to raise 15,000 euros to finance six months of their activity. In the Czech Republic, the web-based channel DVTV in collaboration with the Economia media house launched a crowdfunding campaign in 2014 and raised over CZK 2 million (circa 74,000 euros).

There are also examples of initiatives that adopt crowdfunding as their modus operandi, as opposed to using it as an occasional fundraising tool. The German Krautreporter and the Dutch De Correspondent aim at developing a longer relationship with their users through fixed annual subscription fees and the De Correspondent news site claims to be created to cater to the needs of the reader, as opposed to pleasing advertisers and investors: "They wanted to make a newsroom that wouldn't rush to liveblog the aftermath 
of a terrorist attack, but instead look at 'the bigger developments behind such an attack, such as social inequality'" (Bullard, 2016). Many of the initially successful crowdfunding initiatives last only for a few years, including some prominent examples like Contributoria. com and Spot.us. Insiders from the media industry emphasize that to make crowdfunding initiatives sustainable a lot of effort needs to be invested into promotion, moderation of commenting, and dealing with challenging users, as well as to ensure that the published pieces are of high quality.

In addition to donation-based crowdfunding, the Monitor also detects cases of investment-based crowdfunding, which means that a media organization issues equity instruments to crowd-investors through a platform. One of the prominent examples is the record-breaking El Español, the Spanish news site that raised 3,6 million euros through the sale of shares to over 5,600 shareholders. In this way readers, mostly small equity holders, have become investors. Pedro J Ramirez, the founder of El Mundo, one of the largest printed daily newspapers in Spain, is behind the El Español. Ramirez stated that he would listen to El Espanol's small equity holders "who will have what he calls a 'shareholder button' so that they can comment directly on the site's output" (Badcock, 2015) ${ }^{8}$. From the financial point of view, the business model of El Español, relying on both advertising and subscriptions, can be seen as quite traditional. However, it is considered as innovation within the framework of this paper, as "existing knowledge is implemented in new contexts and (...) this opens up new possibilities" (Storsul and Krumsvik, 2013: 17).

The crowdfunding concept is closely related to crowdsourcing (see e.g. Carvajal et al., 2012) and we have found several instances of innovations that combine both these tools. The Finnish crowdfunded Rapport enables readers to select which topics and journalists to fund, and to suggest future reporting themes. Likewise, De Correspondent is a crowdfunding platform and, at the same time, when its reporters are working on a story, they ask members to send in tips or ask questions. As the foregoing suggests, these media do not see their readers as simple consumers but rather as citizens with the right of expressing opinions and of contributing to the actual production of news. The De Correspondent manifesto asserts that the aim is to establish "a lasting and meaningful relationship with its readers. Seen as members of a community rather than simply consumers of content, readers will be asked to weigh in on the investment of new funds and encouraged to contribute their expertise on specific topics." (Bullard 2016; and De Correspondent undated).

In sum, we found many innovations in terms of crowdfunding and crowdsourcing. Table 2 provides an overview of the types of initiatives identified by the Monitor, categorized by the level of participation. Crowdfunding and crowdsourcing initiatives stretch across all levels of participation, from low, where users make donations without clear returns, to high, where users are empowered to decide which topics and journalists to fund. Some of the emerging innovations apply both crowdfunding and crowdsourcing tools, thereby contributing to redefining the role of the audience. These latter initiatives tend to establish a long-term relationship with their audience and involve them in the

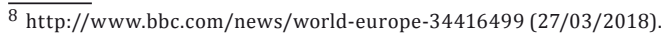


news creation cycle, whereby it can be argued that people are perceived more as citizens than just consumers. It is worth noting that the most common types of crowdfunding identified by the Monitor are still donation-based crowdfunding, where users are involved to a very low degree. However, it should not be neglected that the vast majority of these crowdfunding initiatives offer analytical, investigative, and in general informative content that traditionally relates more with a citizen- than consumer-oriented approach.

Table 2. Crowdfunding (CF) and crowdsourcing (CS) initiatives identified by the Monitor categorized by the level of participation

\begin{tabular}{lll} 
Low & Medium & High \\
$\begin{array}{ll}\text { CF: Users make donations } \\
\text { without clear returns }\end{array}$ & CF: users can become shareholders or & CF: people can decide \\
(e.g. DVTV) & CS: users can suggest reporting themes, & which topics and \\
& $\begin{array}{l}\text { send in tips or ask questions, contribute } \\
\text { with their own expertise (e.g. De }\end{array}$ & (e.g. Rapport) \\
& Correspondent) & \\
\hline
\end{tabular}

\section{CONCLUSION}

The contribution of this paper is twofold: it maps media innovation across Europe, and represents a first attempt to understand whether media organizations seek to reinvent their relations with audiences through these innovations, or if they primarily look for a compensation for revenue loses. First, we analyzed both legacy media and completely new endeavors in thirty European countries with the support of the innovation radar (Sawhney et al., 2006). The radar informed our initial analysis and helped us to identify the most vivid line of innovation in relation to 'customers'. Along this line of innovation, the most prominent cases were instances of crowdfunding and crowdsourcing, as well as paywalls.

Second, to understand if users are conceived primarily as citizens or as consumers in the instances of media innovation categorized mainly within the anchor of 'customers', we focused on the degree to which users are involved in production of content and in management of media organizations. We took inspiration in Jönsson and Örnebring's (2011) and IAP2 (2007) participation frameworks, distinguishing between media features that allow low, medium or high level of participation, and assumed that on the low end of the spectrum of participation users are considered as consumers, while on the medium and high ends users are increasingly seen as citizens.

Our analysis showed that crowdfunding and crowdsourcing innovations stretch across all levels of participation, from low, where users make donations without clear returns, to high, where users are empowered to decide which topics and journalists to fund. However, the most common types of crowdfunding detected were donation-based crowdfunding, where users are involved to a very low degree. From these findings we 
conclude that although some of the innovations taking place in Europe are related to the civic values of media, they do not alter the relationship with audiences significantly, as in most cases they do not allow participation of users in the content- and business-related decision making. There are only a few cases of crowdfunding that strive for higher user engagement levels, e.g. involving users in decisions about topics, themes and personnel that would carry out journalistic work, while none of the observed paywall types qualifies for a higher level of participation.

Some study limitations need to be acknowledged. Our findings are based on the most prominent cases of innovation, noted and reported by national researchers. Furthermore, our simplified analytical framework allowed only for a basic understanding of the level of participation and empowerment of users. However, we hope that our findings can serve as a starting point for more in-depth research on media innovation and on relations between media and their users. In the future, a more nuanced assessment and more research into categorization and definition of different types of participation will be needed. Moreover, as pointed out by reviewers of this article, it would be interesting to examine what it means in practice to have news stories sponsored. Does crowdfunding allow audiences with most resources to control the news agenda? Is there a potential move towards an advertorial model? Or does crowdsourcing result in less special-interest influence on news?

\section{References}

>Aitamurto, Tanja (2015) The role of crowdfunding as a business model in journalism: A fivelayered model of value creation, pp. 189-205in Chin, Bertha, Bennett, Lucy and Jones, Bethan (eds.) Crowdfunding the Future: Media Industries, Ethics and Digital Society. New York: Peter Lange. $>$ Aitamurto, Tanja (2011) The Impact of Crowdfunding on Journalism. Journalism Practice 5 (4): 429 445. DOI: $10.1080 / 17512786.2010 .551018$.

>Arnstein, Sherry R. (1969) A Ladder Of Citizen Participation. Journal of the American Planning Association 35 (4): 216-224. DOI: 10.1080/01944366908977225.

>Aslama, Minna and Napoli, Philip M. (2010) Diversity 2.0: Rethinking Audiences, Participation, and Policies. McGannon Center Working Paper Series. Paper 27. http://fordham.bepress.com/mcgannon_ working_papers/27.

>Badcock, James (2015) Spain Crowdfunded News Site El Espanol Aims for Success. BBC (3 October 2015). http://www.bbc.com/news/world-europe-34416499 (27/03/2018).

>Bond, Shannon (2017) Google and Facebook Build Digital Ad Duopoly. Financial Times (14 March 2017). https://www.ft.com/content/30c81d12-08c8-11e7-97d1-5e720a26771b (26/06/2018).

>Bullard, Gabe (2016) Crowdfunding the News. Nieman reports (26 September 2016). http:// niemanreports.org/articles/crowdfunding-the-news/ (28/03/2018).

$>$ Carlson, Matt (2014) When news sites go native: Redefining the Advertising-editorial Divide in Response to Native Advertising. Journalism 16 (7): 849 - 865. DOI: 10.1177/1464884914545441. >Carson, Andrea (2015) Behind the Newspaper Paywall - Lessons in Charging for Online Content: a Comparative Analysis of Why Australian Newspapers are Stuck in the Purgatorial Space between Digital and Print. Media, Culture \& Society 37 (7): 1022 - 1041. DOI: 10.1177/0163443715591669. >Carvajal, Miguel, García-Avilés, José A. and González, José L. (2012) Crowdfunding and Non-profit Media. Journalism Practice 6 (5-6): 638-647. DOI: 10.1080/17512786.2012.667267.

>Casero-Ripollés, Andreu and Izquierdo-Castillo, Jessica (2013) Between Decline and a New Online Business Model: The Case of the Spanish News Industry. Journal of Media Business Studies 10 (1): 63-78. DOI: 10.1080/16522354.2013.11073560. 
$>$ De Correspondent (undated). De Correspondent Manifest. https://decorrespondent.nl/manifest (20/03/2018).

>De Vreese, Claes H. and Boomgaarden, Hajo G. (2006) Media Effects on Public Opinion about the Enlargement of the European Union. Journal of Common Market Studies 44 (2): 419-436. DOI: 10.1111/j.1468-5965.2006.00629.x.

>European Commission (2016) Crowdfunding in the EU Capital Markets Union (Commission Staff Working Document). https://ec.europa.eu/info/system/files/crowdfunding-report-03052016_ en.pdf (14/02/2018).

>García-Avilés, José Alberto (2012) Roles of Audience Participation in Multiplatform Television: From Fans and Consumers, to Collaborators and Activists. Participations 9 (2): 429-447.

$>$ Goldmedia (2015) Wirtschaftliche Lage des Rundfunks in Deutschland 2014/2015. https://www. blm.de/files/pdf1/151210_Goldmedia_Wirtschaftliche_Lage_Deutschland_gesamt_neu2.pdf (24/03/2018).

$>$ Goyanes, Manuel (2014) An Empirical Studies of Factors that Influence the Willingness to Pay for Online News. Journalism Practice 8 (6): 742-757. DOI: 10.1080/17512786.2014.882056.

$>$ Hardy, Max (2015) Reflections on the IAP2 Spectrum. http://maxhardy.com.au/reflections-on-theiap2-spectrum/ (27/06/2018).

>IAP2 (2007). IAP2 Spectrum of Public Participation. http://c.ymcdn.com/sites/www.iap2.org/ resource/resmgr/imported/IAP2\%20Spectrum_vertical.pdf (12/02/2018).

>Jackson, Dan (2007) Citizens, Consumers and the Demands of Market-Driven News, pp. 141-161 in Lilleker, Darren and Scullion, Richard (eds.) Voter as Consumer: Imaging the contemporary electorate. Cambridge: Cambridge Scholars Publishing.

>Jenkins, Henry (2006) Convergence Culture: Where Old and New Media Collide. New York: New York University Press.

$>$ Jenkins, Henry and Deuze, Mark (2008) Convergence Culture. Convergence 14 (1): 5-12. DOI: $10.1177 / 1354856507084415$.

$>$ Jian, Lian and Shin, Jieun (2015) Motivations Behind Donors' Contributions to Crowdfunded Journalism. Mass Communication and Society 18 (2): 165-185. DOI: 10.1080/15205436.2014.911328.

>Jönsson, Anna Maria and Örnebring, Henrik (2011) User Generated Content and the News.

Journalism Practice 5 (2): 127-144. DOI: 10.1080/17512786.2010.501155.

$>$ Küng, Lucy (2015) Innovators in Digital News. (Extract). Reuters Institute for the Study of Journalism. http://reutersinstitute.politics.ox.ac.uk/sites/default/files/research/files/Innovators\%2520in $\% 2520$ Digital\%2520News\%2520Extract.pdf (17/02/2018).

>Laursen, Jesper and Stone, Martha (2016) Native Advertising Trends 2016: The News Media Industry. Native Advertising Institute (NAI) and the International News Media Association (INMA). https://nativeadvertisinginstitute.com/wpcontent/uploads/2016/10/TrendReportNewsMedia16.pdf $(17 / 02 / 2018)$.

>Lewis, Justin, Inthorn, Sanna, and Wahl-Jorgensen, Karin (2005) Citizens or consumers? What the media tell us about political participation. Maidenhead, UK: McGraw-Hill/Open University Press. >Lessig, Lawrence (2008) Remix: Making Art and Commerce Thrive in the Hybrid Economy. New York: Penguin. DOI: 10.5040/9781849662505.

>Löfgren Nilsson, Monica and Örnebring Henrik (2016) Journalism Under Threat. Journalism Practice 10 (7): 880-890. DOI: 10.1080/17512786.2016.1164614.

$>$ Matteo, Stéphane and Zotto, Cinzia D. (2015) Native Advertising, or How to Stretch Editorial to Sponsored Content Within a Transmedia Branding Era, pp. 169-185 in Siegert G., Förster K., ChanOlmsted S., Ots M. (eds.) Handbook of Media Branding. Springer, Cham. DOI: 10.1007/978-3-31918236-0_12.

$>$ McQuail, Denis (2010) Mass Communication Theory. (6th ed.). New York: Sage Publications Ltd. $>$ Mellado, Claudia and van Dalen, Arjen (2017) Challenging the Citizen-Consumer Journalistic Dichotomy: A News Content Analysis of Audience Approaches in Chile. Journalism \& Mass Communication Quarterly 94 (1): 213-237. DOI: 10.1177/1077699016629373. 
$>$ Mitchelstein, Eugenia (2011) Catharsis and Community: Divergent motivations for audience participation in online newspapers and blogs. International Journal of Communication 5: 2014-2034. >Napoli, Philip M. (2011) Audience Evolution: New Technologies and the Transformation of Media Audiences. New York: Columbia University Press.

$>$ Newman, Nic with Fletcher, Richard, Kalogeropoulos, Antonis, Levy, David A. L. and Kleis Nielsen, Rasmus (2017) Digital News Report 2017. Reuters Institute for the Study of Journalism, Oxford University. https://reutersinstitute.politics.ox.ac.uk/sites/default/files/Digital\%20News\%20 Report\%202017\%20web_0.pdf (12/02/2018).

$>$ Newman, Nic, Fletcher, Richard, Levy, David A. L. and Kleis Nielsen, Rasmus (2016) Digital News Report 2017. Reuters Institute for the Study of Journalism, Oxford University. http://reutersinstitute. politics.ox.ac.uk/sites/default/files/research/files/Digital\%2520News\%2520Report\%25202016.pdf (12/02/2018).

>Picard, Robert G. (2014) New Approaches to Paid Digital Content. Digital News Report 2017. Reuters Institute for the Study of Journalism, Oxford University. http:// www.digitalnewsreport.org/ essays/2014/new-approaches-to-paid-digital-content/ (12/02/2018).

>Pickard, Victor and Williams, Alex T. (2014) Salvation or Folly? The Promise and Perils of Digital Paywalls. Digital Journalism 2 (2): 195-213. DOI: 10.1080/21670811.2013.865967.

>Rosen, Jay (2006) The People Formerly Known as the Audience. PressThink (27 June 2006). http:// archive.pressthink.org/2006/06/27/ppl_frmr.html (12/02/2018).

>Sawhney, Mohanbir, Wolcott, Robert C. and Arroniz, Inigo (2006) The 12 Different Ways for Companies to Innovate. MIT Sloan (1 April 2006). https://sloanreview.mit.edu/article/the-differentways-for-companies-to-innovate/ (12/02/2018).

>Scammell, Margaret (2000) The Internet and Civic Engagement: The Age of the Citizen-Consumer. Political Communication 17 (4): 351-355. DOI: 10.1080/10584600050178951.

>Storsul, Tanja and Krumsvik, Arne H. (eds.) (2013) Media Innovations: A Multidisciplinary Study of Change. Gothenburg: Nordicom.

$>$ Vladica, Florin and Davis, Charles H. (2009) Business Innovation and New Media Practices in Documentary Film Production and Distribution: Conceptual Framework and Review of Evidence in A. Albarran, P. Faustino and R. Santos (eds.) The Media as a Driver of the Information Society. Lisbon: Media XXI/Formal Press and Universidade Catolica Editora.

$>$ Viscovi, Dino and Gustafsson, Malin (2013) Dirty Work, pp. 85-101 in Olsson, Tobias (ed.) Producing the Internet. Gothenburg: Nordicom, University of Gothenburg.

$>$ Ward, Janelle and de Vreese, Claes (2011) Political Consumerism, Young Citizens and the Internet. Media Culture \& Society 33 (3): 399-413. DOI: 10.1177/0163443710394900.

>Zaripova, Adilya (2017) "My Boss is 18,000 people". Journalism practices in crowdfunded media organizations. MedieKultur, 62: 100-118. DOI: 10.7146/mediekultur.v33i62.24767. 


\title{
MEDIJSKA INOVACIJA U EUROPI I PREISPITIVANJE ODNOSA PREMA PUBLIKAMA: IZMEĐU GRAĐANA I POTROŠAČA
}

\author{
Iva Nenadić :: Alina Ostling
}

SAŽETAK Razvoj i široka primjena novih tehnologija građanima je omogućila sudjelovanje u različitim fazama proizvodnje, distribucije i promocije vijesti i drugih sadržaja kao nikada ranije. Kako bi odgovorili na promjene u informacijskom okruženju, mediji i novinari pokušavaju uvesti inovacije u poslovni model. Stoga ovaj rad postavlja sljedeće pitanje : u pokušaju da preispitaju poslovni model, preispituju li mediji $i$ novinari diljem Europe i svoj odnos s publikama? Preciznije, odnosi li se postojeća inovacija prema publikama prvenstveno kao prema građanima ili kao prema potrošačima? Analiza se temelji na podacima prikupljenima od nacionalnih istraživačkih timova kroz projekt Media Pluralism Monitor 2016, koji je proveden u 28 zemalja Europske unije, Crnoj Gori i Turskoj. Rezultati pokazuju kako su najvidljiviji pokušaji inovacije u obuhvaćenim državama crowdfunding/crowdsourcing i različite vrste paywalla, što se može tumačiti kao pokušaj da se od publike nadoknade smanjeni prihodi od oglašavanja. Istovremeno, tek nekoliko inicijativa značajnije preispituje svoj odnos s publikom, dajući im veću moć odlučivanja (bilo da se radi o odlučivanju o sadržaju ili o poslovnoj strategiji). Publike se u velikoj mjeri i dalje tretira primarno kao potrošače, a njihova razina participacije ostaje ograničena.

\section{KLJUČNE RIJEČI}

MEDIJI, POSLOVNA INOVACIJA, CROWDFUNDING, PAYWALL, PARTICIPACIJA, PUBLIKE, GRAĐANI, POTROŠAČI

Bilješka o autoricama

Iva Nenadić :: Sveučilište u Zagrebu, Fakultet političkih znanosti / Centar za medijski pluralizam i slobodu medija, Europski sveučilišni institut, Firenca :: iva.nenadic@fpzg.hr Alina Ostling :: GLOBALCIT Programme, Europski sveučilišni instutut, Firenca :: alina.ostling@eui.eu 